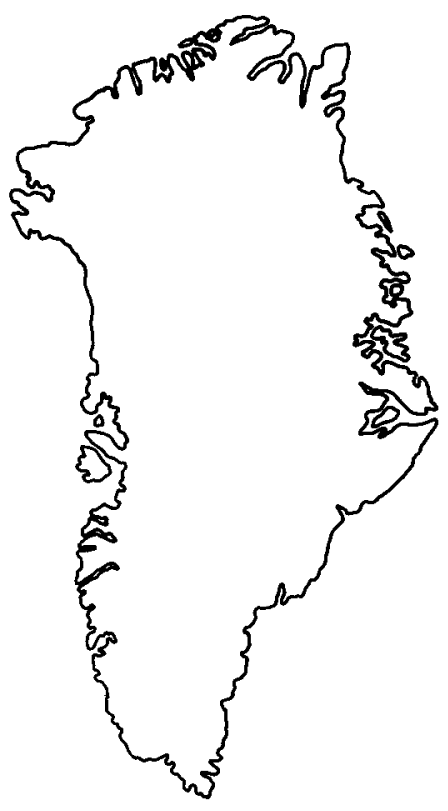

\title{
Late Proterozoic(?) to Silurian stratigraphy of southern Wulff Land, North Greenland
}

\author{
John M. Hurst and John S. Peel
}

\begin{abstract}
Late Proterozoic(?) to Silurian clastic and carbonate sequences overlying crystalline basement in southern Wulff Land are described. Strata older than early Middle Ordovician compare best with the sequence to the east, in Peary Land, while late Middle Ordovician to Upper Silurian sediments show greater similarity to outcrops in western North Greenland.
\end{abstract}

J.M.H. \& J.S.P. Grønlands Geologiske Undersøgelse, Øster Voldgade 10, DK-1350 København K, Danmark.

No systematic description of the geology of southern Wulff Land (fig. 1) has been published although scattered observations have been made by Koch (1920). Geologists of Greenarctic Consortium visited the area during 1969 in the course of regional exploration and some results of their work have been referred to by Dawes (1976a) in his summary of North Greenland geology, notably the presence of Late Proterozoic(?) and fossiliferous Early Cambrian above the metamorphic basement. With the initiation of the North Greenland Project in 1978, it became practicable to briefly visit southern Wulff Land with the aim of establishing comparative reference sections through the late Proterozoic(?) - Silurian sedimentary sequence overlying the basement.

Wulff Land occupies a key position in North Greenland geology with its relatively complete Lower Palaeozoic sequence (fig. 2) providing a link between comparatively well known sections in Inglefield Land, Washington Land and Hall Land, to the west (Troelsen, 1950; Dawes 1976a; Henriksen \& Peel, 1976) and equivalent, but somewhat dissimilar, sections in Peary Land, to the east (Jepsen, 1971; Christie \& Peel, 1977). Crystalline basement outcropping at the head of Victoria Fjord provides the northernmost known exposures of Shield rocks in Greenland. Dawes \& Soper (1973) employed the term Victoria Fjord Arch for this tectonically high area, penetrating north toward the North Greenland geosyncline, which has seemingly exerted a profound influence on sedimentary deposition in North Greenland during the late Proterozoic and early Palaeozoic.

Two thin sedimentary units of late Proterozoic (or earliest Cambrian) age are recognised in southern Wulff Land and tentatively correlated with strata in Peary Land. Overlying sandstones and shales are assigned to the Buen Formation of Peary Land, and have yielded Early Cambrian fossils from the upper beds. The Buen Formation is followed by dolomites which are grouped 


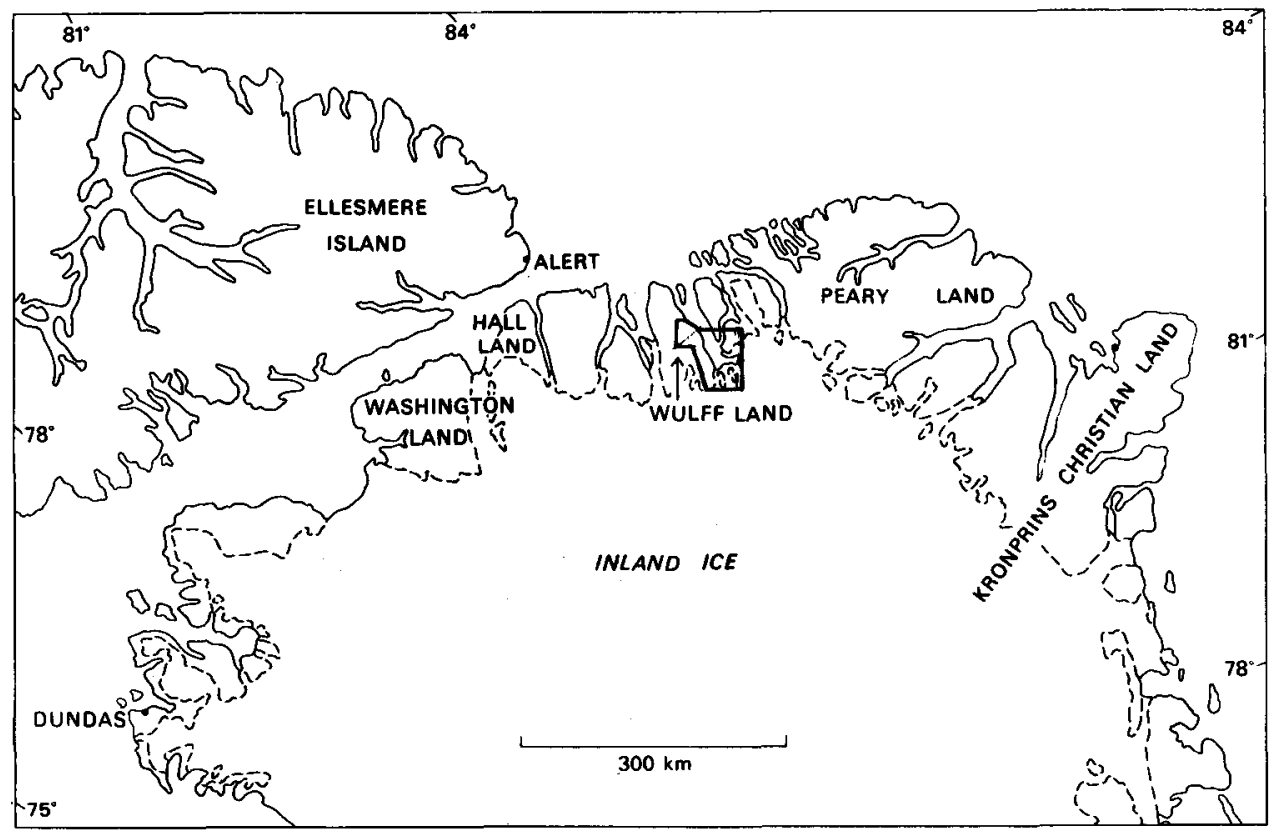

Fig. 1. Northern Greenland and adjacent Ellesmere Island showing the location of the study area (fig. 2).

together provisionally and referred to as a single unit (Brønlund Fjord Group - Wandel Valley Formation) after lithostratigraphical names employed in Peary Land, but probably include strata of Early, Middle and Late Cambrian, and Early and Middle Ordovician ages. Succeeding cliff-forming, mainly Middle - Upper Ordovician limestones are referred to the Gonioceras Bay, Troedsson Cliff, Cape Calhoun and Aleqatsiaq Fjord Formations on account of their similarity with the type area in Washington Land.

As in other areas of North Greenland, the Silurian is divisible into two distinct lithological units - shelf carbonates and basinal clastics. Thus, two composite reference profiles were established near the northern end of the large easternmost lake in southern Wulff Land (fig. 2). There appears to be a complete succession in the carbonates from the underlying Upper Ordovician to probably at least Upper Llandovery (Telychian). The Silurian carbonate units are complex due to the presence of carbonate buildups at two distinct stratigraphic levels. The vertical and horizontal facies changes associated with the carbonate buildups cause difficulties in lithostratigraphic correlation along the strike. The shelf carbonates pass abruptly northward into a thick clastic sequence of shales, silts and turbidites, which appears to range in age from at least Late Llandovery (Telychian) to Ludlow. At this contact, but topographically below the platform sediments, a third carbonate buildup horizon occurs. Younger turbidite beds are undoubtedly present to the north, but were not examined.

The Silurian carbonates are about $600 \mathrm{~m}$ in thickness and are divided into four formations. At least $650 \mathrm{~m}$ of basinal clastics are present, representing three formations. Due to the preliminary nature of this report, formal names are not assigned to the Silurian formations and members and type sections are not designated. 


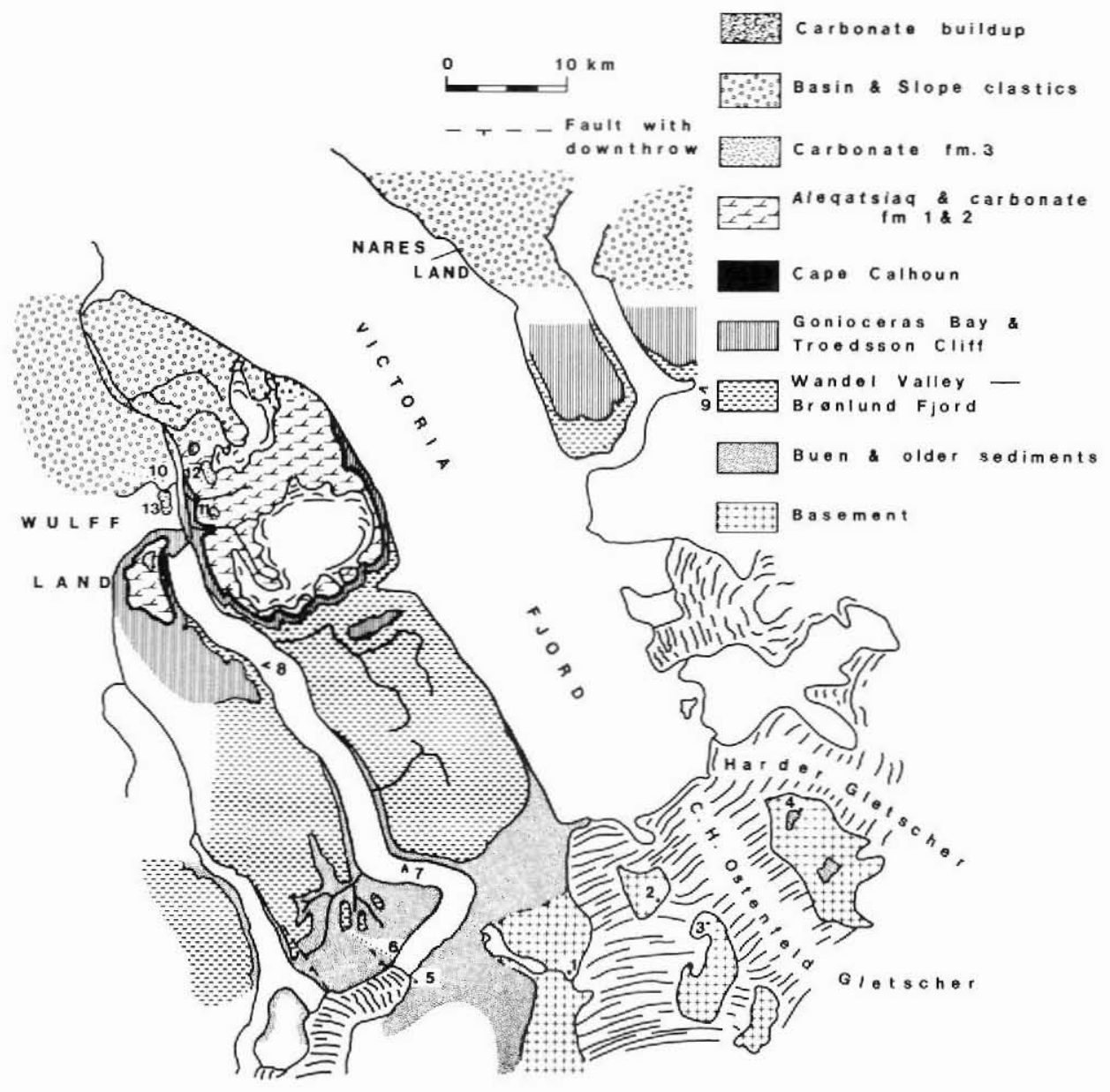

Fig. 2. Geological map of southern Wulff Land, for location see fig. 1.

\section{Crystalline Basement}

Although the presence of crystalline basement at the bead of Victoria Fjord has been suggested for some time from aerial reconnaissance (Haller, 1961), previous field observations are restricted to those made by Greenarctic Consortium during 1969. Dawes (1976a) has summarised the known geology.

Brief helicopter reconnaissance stops were made on four outcrops of crystalline basement (fig. 2, localities 1-4) permitting the collection of six rock samples. P.R. Dawes (GGU unpublished internal report) comments that the samples confirm earlier reports, indicating that the basement is composed of an amphibolite facies, granite-gneiss complex containing presumably concordant bodies of amphibolites. The undeformed basic dykes that cut the complex were not examined.

Dawes reports that the basement samples fall into two groups, granitic and amphibolitic. Amphibolites collected from localities 2,3 and 4 are all schists containing green hornblende and 
plagioclase, with or without biotite and/or garnet. The sample from the latter locality is a quartz-bearing garnet amphibolite. The granitic samples (localities 1, 3 and 4) are pink, medium grained and contain both plagioclase and potash feldspar, with or without biotite. The sample from locality 1 is leucocratic and rather homogenous, the others are biotite foliated, granitic gneiss. Mineral assemblages of the samples indicate metamorphism in the almandine-amphibolite facies.

\section{Age and correlation}

The age of the crystalline basement is as yet unknown, although overlying sediments are of Late Proterozoic(?) or earliest Cambrian age. Dawes comments that amphibolitic and granitic rocks make up parts of the crystalline basement complex in Inglefield Land. some $500 \mathrm{~km}$ to the south-west. Pink and red granites of the Etah meta-igneous complex in Inglefield Land are similar to rocks in the present collection. The crystalline basement of the Inglefield Land - Thule region was affected by a high-grade regional metamorphic event of Hudsonian age, with $\mathrm{K}$-Ar dates ranging from about 1880 to 1610 m.y. (Larsen \& Dawes, 1974), although older material is undoubtedly present.

\section{Basement - sediment contact}

Direct contact between the basement metamorphic complex and overlying sediments was only examined at locality 4 , the northernmost outlier on this nunatak (fig. 2). A breccia with calcareous cement, containing clasts of a variety of rock types, rests on deeply dissected metamorphic basement (fig. 3). The breccia lies in gullies several meters in depth, with steep or overhanging sides. Blocks of basement metamorphic rocks, dolomites (including pisolite) and feldspathic sandstone up to $2 \mathrm{~m}$ in diameter were observed. In hand specimen, the matrix supporting the larger clasts is mainly composed of well rounded, poorly sorted quartz grains and small pebbles with a buff coloured, calcareous cement; assorted smaller clasts $(1-3 \mathrm{~cm})$ include angular fragments of shale, granite, sandstone and a variety of dolomites.

It was not possible to ascertain the thickness of the breccia or the presence of overlying sediments. However, it is considered likely that the sediments form the lowest beds of the un-named dolomite formation, described below.

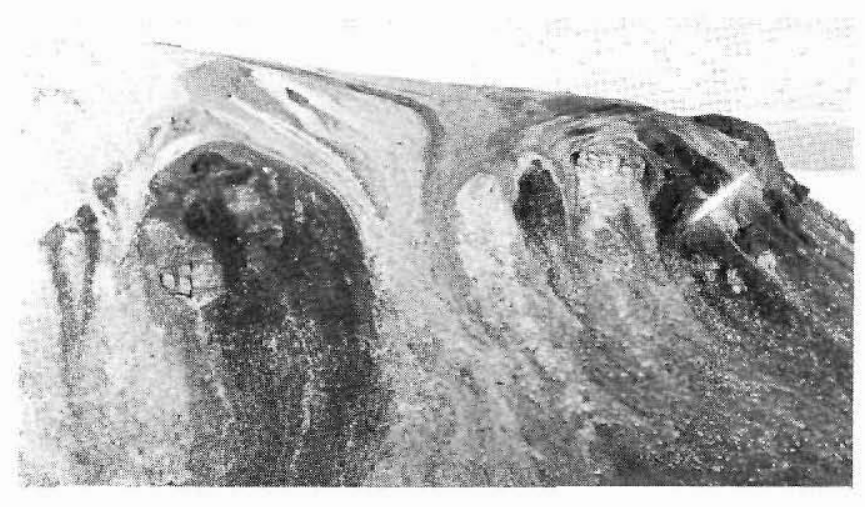

Fig. 3. Pale weathering sediments overlying deeply disected crystalline basement at locality 4 (fig. 2) with Nares Land beyond. 


\section{Un-named dolomite formation}

This formation was only examined at locality 5 (fig. 2) although similar carbonate cemented breccia directly overlying the metamorphic basement at locality 4 may belong here. Between 20 and $30 \mathrm{~m}$ of dolomitic rocks are exposed, but the outcrops are disturbed by solifluxion and are drift plastered.

\section{Lithology}

The lowest exposures consist of $2-3 \mathrm{~m}$ of pale thin bedded dolomites followed by a $50 \mathrm{~cm}$ thick dolomitic breccia. About $10 \mathrm{~m}$ of overlying dolomites are generally laminated, sometimes shaly, pale weathering, grey or pale buff in colour with some nodules or lenticles of black and white cherts. The highest exposed beds consist of $5-10 \mathrm{~m}$ of dolomitic breccia in which poorly sorted, angular to subrounded clasts (coarse grains to $1 \mathrm{~m}$ boulders) of quartz, granitic bascment, various dolomites (including oolites) and sandstones are supported by a buff coloured matrix of dolomitic sand (fig. 4).

\section{Age and Correlation}

A satisfactory correlation of the un-named dolomite formation with other units elsewhere in North Greenland is not firmly established. However, the Portfjeld Formation of Peary Land (Jepsen, 1971) is mainly dolomites and includes a breccia in its upper part not unlike the Wulff Land breccia, although without the metamorphic blocks. The Portfjeld Formation, of uncertain late Proterozoic to earliest Cambrian age, is overlain seemingly conformably by clastics of the Buen Formation in Peary Land and this unit is also recognised in Wulff Land in a somewhat modified form. In Peary Land, the Portfjeld Formation overlies the Morænesø Formation, a thin

Fig. 4. Breccia of the unnamed dolomite formation with sedimentary and crystalline clasts in a dolomitic sand matrix (fig. 2. locality 5).

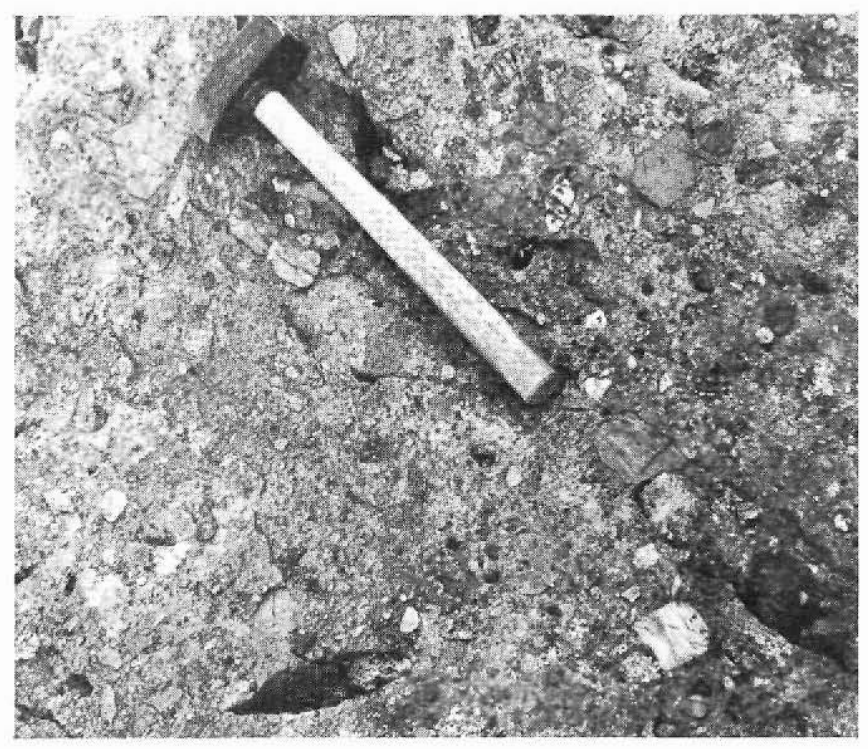


series of sandstones, some stromatolitic dolomites and breccias interpreted as tillite. The Morænesø Formation lies on the eroded surface of the Proterozoic Inuiteq Sø Formation (Jepsen, 1971) which is dominated by large-scale cross-bedded, reddish weathering sandstones. Blocks of similar sandstone have been observed in the calcareous breccia overlying the metamorphic basement at locality 4 .

On the basis of available evidence, a tentative correlation of the un-named dolomite formation with the upper part of the Portfjeld Formation of Peary Land is considered the most appropriate.

\section{Lithology}

\section{Feldspathic sandstone unit}

About $10 \mathrm{~m}$ of large-scale cross-bedded sandstone forms a conspicuous red weathering stripe above the dolomites at locality 5 , at the foot of the cliff. The sandstone is unfossiliferous, poorly sorted, medium to coarse grained with small subangular to rounded quartz pebbles and scattered feldspar. The contact with the underlying dolomites, see above, was not observed.

\section{Age and Correlation}

The unit may represent the basal beds of the overlying Buen Formation of Early Cambrian age, examined at locality 6 across the lake, but some tens of meters of unexposed section intervene. A second, but less likely possibility is that the sandstone unit correlates with a thin sandstone near the top of the Portfjeld Formation (Late Proterozoic or Early Cambarian) of Peary Land (Jepsen, 1971). In westernmost Peary Land, field work during 1978 demonstrated a largescale cross-bedded grit similar to the Wulff Land deposit in this stratigraphic position. In the former area, dolomites overlie the grit but on account of poor exposure no evidence of their occurence in Wulff Land was noted.

\section{Definition}

\section{Buen Formation}

Jepsen (1971) gave the name Buen Formation to a unit of sandstones and shales of probable Early Cambrian age in the Jørgen Brønlund area of Peary Land. Field work during 1978, confirmed the brief report by Dawes (1976b), that established that the formation extends westwards beyond Peary Land into Freuchen Land. A substantial thickness $(c .550-600 \mathrm{~m})$ of sandstones and overlying black shales and silts in southern Wulff Land can be readily assigned to the Buen Formation. Early Cambrian fossils have been collected from the upper levels of the formation in both areas.

The Buen Formation outcrops extensively in southern Wulff Land, a reconnaissance section being measured at locality 6 (fig. 2). The lower hill slopes are drift covered but there seems little doubt that the formation overlies the feldspathic sandstone unit examined across the lake at locality 5 . The formation can be divided into a lower resistant unit (c. $450-550 \mathrm{~m}$ ) predominantly composed of various sandstones and subordinate silts, and a poorly exposed upper recessive unit $(c .100-150 \mathrm{~m})$ of mainly shales, silts and thin sandstones, with a thin limestone bed near the top. 
Fig. 5. Quartzite with Skolithos, Buen Formation (fig. 2, locality 6).

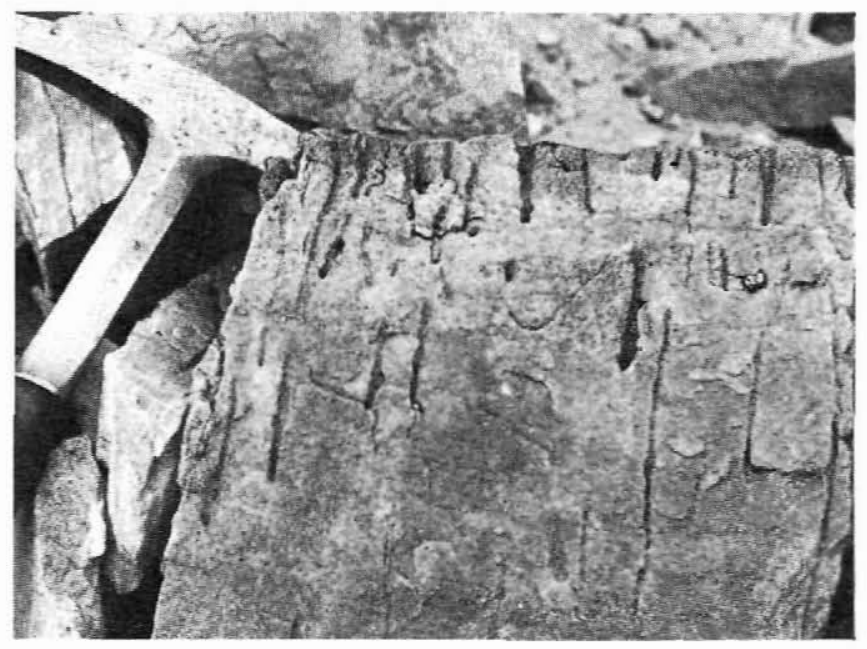

\section{Lithology}

The sandstones of the lower member range from white or grey, coarse grained, massive weathering, large-scale cross-bedded and conglomeratic in character, to finer, greenish weathering, cross-bedded, micaceous, bioturbated sandstones with silty partings. Pale grey, orange-brown weathering, medium to coarse grained quartzites are conspicuous in the upper part of the member and are locally rich in Skolithos (fig. 5). Hillsides formed by the weathered sandstones of the lower member are often conspicuously coloured with reds, yellows and greens the dominant tones.

The overlying recessive member of the Buen Formation in Wulff Land is apparently rich in shales and siltstones although these are poorly exposed in the section at locality 6 . The hardness contrast with the underlying resistant sandstones has resulted in the shale being stripped away to produce characteristisc flat, damp, well vegetated tops to hills in the southern part of the area. with the lower, sandstone member forming the steep hill sides.

Thin, cross-bedded quartzites occur in the lower part of the member, while a $1.5 \mathrm{~m}$ thick bed of bioclastic limestone forms a bench around the hill tops adjacent to section 6 , about $35 \mathrm{~m}$ below the top. The limestone is a coquina composed of pagetid trilobites, broken fragments of olenellids, hyolithids, and inarticulate brachiopods.

The upper contact of the formation with the overlying dolomites was not examined in Wulff Land, but it is apparently well exposed along the lake shore to the north-east of locality 6 (fig. 6 , locality 7 in fig. 2).

\section{Age and Correlation}

Well preserved pagetid triolobites from the coquina near the top of the shale are comparable to Hebediscus marginatus Rasetti, 1967 from the Early Cambrian of New York, referred to Ekwipagetia by Fritz (1973) who reported a similar, but slightly older species from the Sekwi Formation in north-western Canada. A.R. Palmer (pers. comm. 1979) has identified Labradoria, Olenellus, Wanneria?, Hyolithus, Hyolithellus, Pelagiella and Obolella from the same 


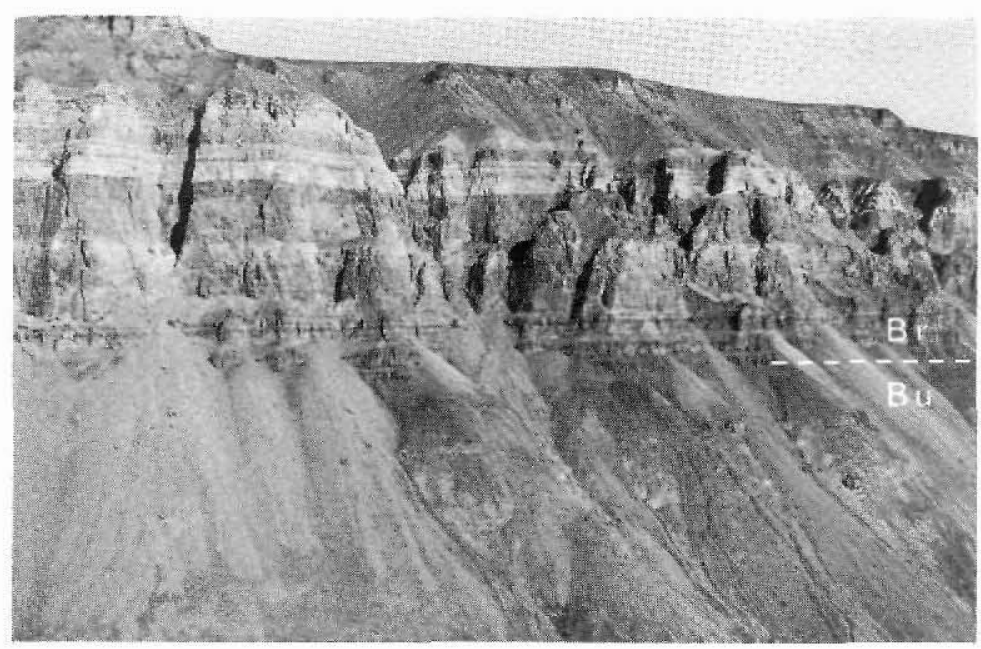

Fig. 6. Cliff-forming dolomites (Br) of the Brønlund Fjord Group - Wandel Valley Formation overlying recessive shales, siltstones and thin sandstones $(\mathrm{Bu})$ of the Buen Formation (fig. 2, locality 7).

collection. Geologists of Greenarctic Consortium (Dawes, 1976a) reported Olenellus, Callavia, Wimanella and Botsfordia from Early Cambrian rocks in southern Wulff Land but the precise locality(s) and horizon(s) are unknown to the authors. Skolithos occurs in the lower sandstones of the Buen Formation in Wulff Land and it is assumed that the entire formation is of Early Cambrian age.

The Buen Formation has not been recognised to the west of Wulff Land. Early Cambrian sandstones in Washington Land informally referred to as the Humboldt formation by Peel (1978) and Jepsen \& Dueholm (1978, fig. 50) include a lower cross-bedded sandstone unit with Skolithos and higher silts and fine sandstones with Cruziana. Early Cambrian fossils have been recovered from a thin dolomitic conglomerate near the top of the formation.

\section{Brønlund Fjord Group - Wandel Valley Formation}

Direct examination of this composite unit was restricted to the small outlier forming the hill top at locality 6 (fig. 2) where a few meters of pale, mottled, vuggy, recrystallised dolomite near to the base of the unit are exposed. These lower dolomites, lying above the Buen Formation, can be compared to basal beds of the Brønlund Fjord Group (Early - Middle Cambrian) of Peary Land, in terms of both lithology and stratigraphic position (Christie \& Peel, 1977; Peel, 1979).

Upper beds of the unit are distinctively black and white banded (figs 6-8) and are readily correlated with the dolomites of the Wandel Valley Formation (Early - Middle Ordovician) in Peary Land. Intervening strata exposed along the lake sides include grey and reddish weathering units but the presence or absence of sandstones in the otherwise apparently largely dolomite formation is not known. It is probable, but unsubstantiated, that these intervening red and grey strata correlate in part with Middle and Upper Cambrian rocks in western Peary Land of the Brønlund Fjord and Tavsens Iskappe Groups (Peel, 1979). 
Fig. 7. Gonioceras Bay Formation and Troedsson Cliff Formation $(\mathrm{G})$ overlying banded dolomites of the Wandel Valley Formation (W) in southern Wulff Land (fig. 2, locality 8).

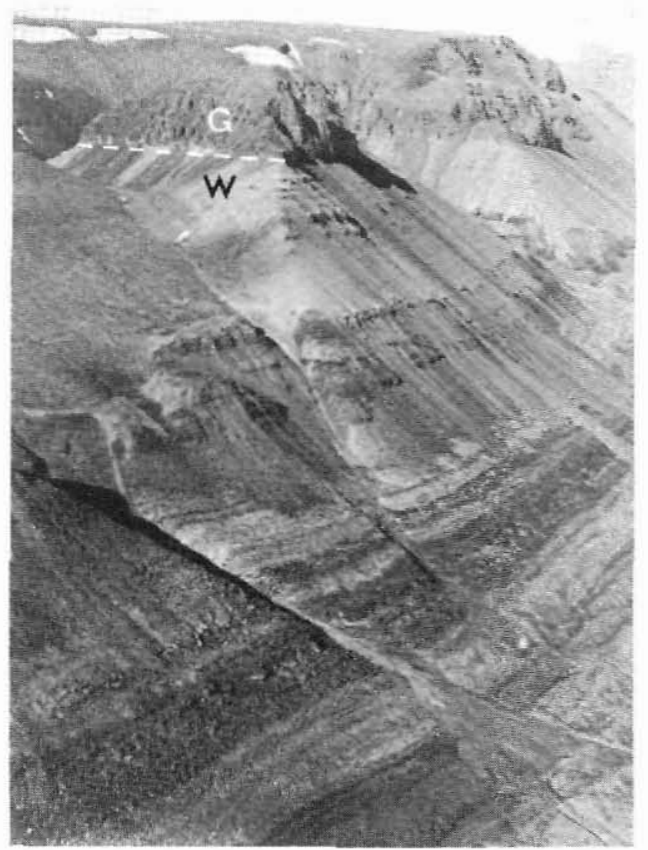

\section{Gonioceras Bay Formation}

This formation was described in Washington Land by Troedsson $(1926,1928)$ and Koch (1929) and re-defined by Troelsen (1950) and Peel \& Hurst (in press). Cliff-forming strata overlying the Wandel Valley Formation in southern Wulff Land (fig. 7) and adjacent Nares Land (fig. 8) are similar in weathering style to the overlying Troedsson Cliff Formation (see below) and are tentatively assigned to the Gonioceras Bay Formation, although direct examination of the unit on the ground was not possible.

In Washington Land, the formation is typically composed of brownish, rather massive weathering, thick bedded, fine, dense, wackestone, whereas the overlying Troedsson Cliff Formation is a little more recessive, with beds of massive weathering limestone alternating with rubbly weathering, nodular limestones. The Gonioceras Bay Formation of Washington Land and Wulff Land is seemingly equivalent to the basal Børglum River Formation of Peary Land (Christie \& Peel, 1977).

\section{Troedsson Cliff Formation}

\section{Definition}

Koch (1929) originally defined this unit in south-west Washington Land, but it is here applied in the redefined sense of Peel \& Hurst (in press). Koch (1929) did not report the presence of this formation outside Washington Land although he did intimate that the closely comparable, underlying, Gonioceras Bay Formation should be present in Peary Land. However, the work of 


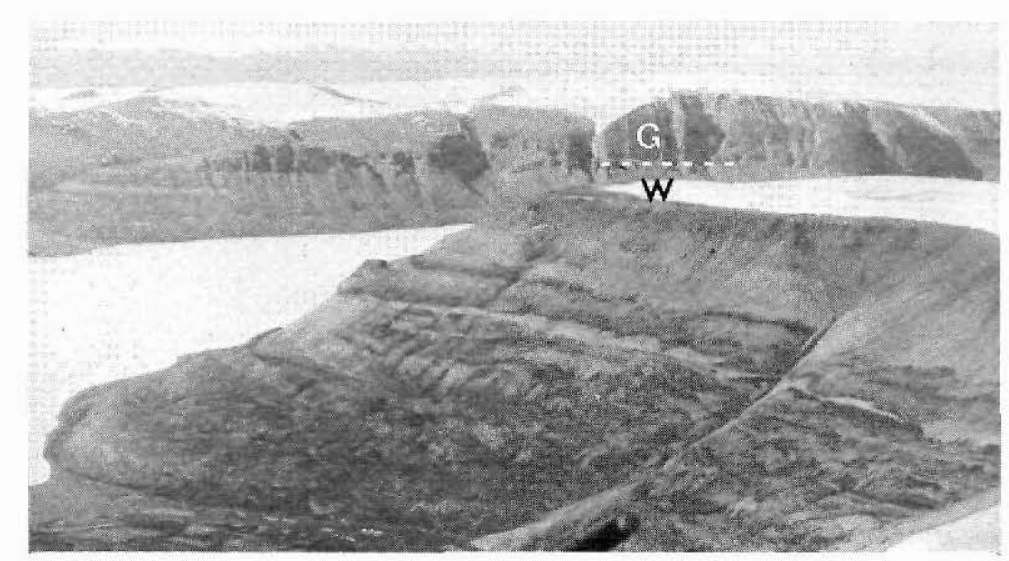

Fig. 8. Cliff-forming limestones of the Gonioceras Bay and Troedsson Cliff Formations $(\mathrm{G})$ overlying banded dolomites of the Wandel Valley Formation (W), Nares Land, fig. 2, locality 9.

Christie \& Peel (1977) demonstrates that neither the Gonioceras Bay Formation nor Troedsson Cliff Formation occur in Peary Land where they are partially or wholly replaced by the Børglum River Formation. Thus, the presence of the Troedsson Cliff Formation in Wulff Land indicates a greater similarity in Late Ordovician time between Wulff Land and Washington Land, than between Wulff Land and Peary Land.

The Troedsson Cliff Formation is a thick unit which forms the lower part of the cliffs and valley floor at the northern end of the major lake (figs 2, 7). As with all the Palaeozoic units, it descends gently northwards due to the regional dip. The total thickness is unknown and only the top $30 \mathrm{~m}$ were examined in detail (fig. 9).

\section{Lithology}

The upper part of the limestone (fig. 2, locality 11) appears uniformly medium bedded in units 50 to $100 \mathrm{~cm}$ thick. On fresh surfaces the sediments are generally dark grey with occasional pinkish tinges, but on weathered surfaces the general dark brown colouration is broken by faint yellowish brown mottling. Some of the mottling is related to burrowing. Most beds are massive with no internal stratification but occasionally a thin unit $(50 \mathrm{~cm})$ develops a nodular crinkly texture which wedges out. These units tend to be of a lighter grey colour. The sediments are predominantly wackestones $(90-95$ per cent) but very thin packestone beds up to $10 \mathrm{~cm}$ thick generally contain the highest faunal content.

\section{Fauna}

The upper part is richly fossiliferous and large Maclurites sp. and orthocone cephalopods are particularly conspicuous, the latter often containing many borings and epizoans. Corals including Saffordophyllum sp., Catenipora sp., Calapoecia sp., Lobocorallium(?) sp. and streptelasmatids are abundant. Other fauna includes the brachiopod Zygospira sp., bivalves, the gastropod Murchisonia sp., bumastine and other trilobite debris and crinoid fragments. As the 
10

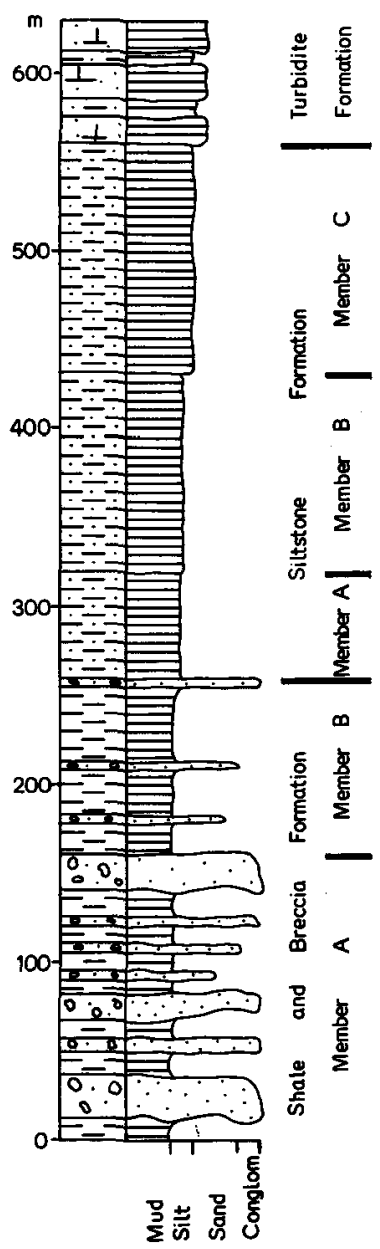

11

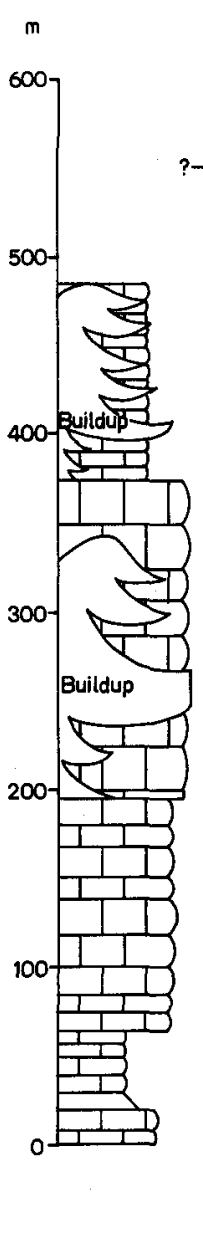

12

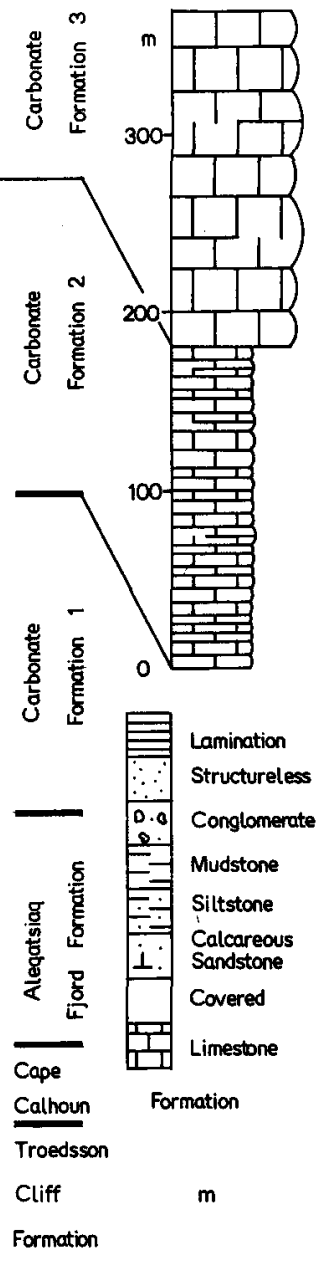

Fig. 9. Simplified sedimentary $\log$ of the Silurian stratigraphic sections. Numbers $10,11 \& 12$ refer to localities shown in fig. 2.

topmost part of this formation is recessive, bedding plane surfaces exhibiting imperfect surface silicification of fossils are common.

\section{Cape Calhoun Formation}

\section{Definition}

The complicated history of nomenclatorial changes surrounding the naming and subsequent recognition of this unit is discussed in detail by Peel \& Hurst (in press). Essentially, the Cape Calhoun Formation as defined by Koch (1929) was embracive and he traced it across North 
Greenland into Peary Land. In the restricted sense of Peel \& Hurst the formation cannot be traced into Peary Land, but is replaced by the Børglum River Formation. Even in the expanded sense of Koch (1929), partially including the underlying Troedsson Cliff Formation and the overlying Aleqatsiaq Fjord Formation, the unit is not present in Peary Land. Thus, its presence in Wulff Land again underlines the stratigraphic similarity with Washington Land and the dissimilarity with Peary Land, during this time interval.

\section{Lithology}

The Cape Calhoun Formation as defined by Peel \& Hurst (in press) is a thin succession of generally recessive, thinly bedded limestones with very thin shale interbeds which conformably follows the Troedsson Cliff Formation (figs 9, 10). Some $40 \mathrm{~m}$ are present in Wulff Land of which the lowest $10 \mathrm{~m}$ in the measured section were scree covered. The limestone beds ( 5 to 20 $\mathrm{m}$ thick) are crinkly or nodular packstones and the interbedded shale wraps around the harder more competent lime beds. The whole unit has a distinctive green colour due mainly to staining caused by the breakdown of the millimetre thick shale interbeds.

\section{Fauna and Age}

Many fossils of the so-called Arctic Ordovician fauna abound in the Cape Calhoun Formation. Large corals e.g. Catenipora sp. and Calapoecia sp., numerous orthocone cephalopods and the gastropod Maclurites sp. are characteristic. The whole faunal assemblage is typical of the Cape Calhoun Formation elsewhere and probably ranges in age from Upper Eden, Maysville to possibly lowest Richmond (Actonian, Onnian and Pusgillian).

\section{Aleqatsiaq Fjord Formation}

\section{Definition}

This formation, erected by Peel \& Hurst (in press) in Washington Land, is represented by 130 $\mathrm{m}$ of sediments in Wulff Land. The Aleqatsiaq Fjord Formation is a massive unit which weathers dark brown in marked contrast to the underlying, recessive, green Cape Calhoun Formation upon which it conformably lies (figs 9, 10).

\section{Lithology}

The contact between the Cape Calhoun Formation and the Aleqatsiaq Fjord Formation is fairly abrupt. The loss of the shaly interbeds of the former formation imparts a thicker stratified and therefore bedded nature to the succeeding formation, although the lower $5 \mathrm{~m}$ are still nodular. Above the basal $5 \mathrm{~m}$ the formation is medium bedded (c. $50 \mathrm{~cm}$ to $2 \mathrm{~m}$ ) and on weathered surfaces it is generally faintly mottled light yellowish brown. The sediments are mainly lime mudstones and wackestones, although in places weak patchy dolomitisation occurs. 


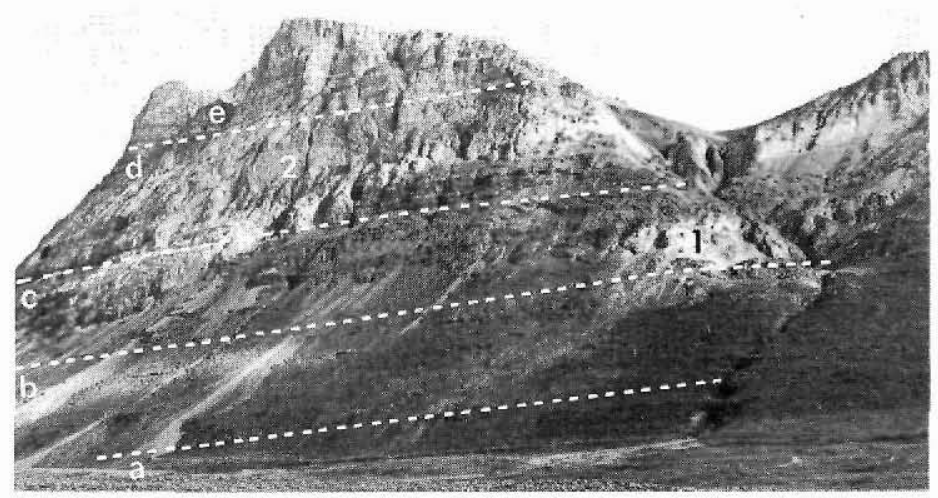

Fig. 10. Upper Ordovician and Silurian strata at locality 11 (fig. 2). a, Cape Calhoun Formation; b, Aleqatsiaq Fjord Formation: c, Silurian carbonate formation 1; d, Silurian carbonate formation 2; e, Silurian carbonate formation $3.1,2$, carbonate buildups.

\section{Fauna and Age}

The fauna of this unit is poor. Large, often recrystallised tabulate coral colonies and actinoceratid cephalopods are the most conspicuous elements. Maclurites sp. is present up to $100 \mathrm{~m}$ from the formation base indicating a probable Ordovician (Richmond) age for that part of the formation. The top $30 \mathrm{~m}$ of the formation may be Silurian (Early Llandovery, Rhuddanian) although there is no unequivocal evidence to indicate this.

\section{Silurian carbonate formation 1}

A very variable sequence of limestones and dolomites, some $185 \mathrm{~m}$ thick. conformably overlies the Aleqatsiaq Fjord Formation (figs 9, 10). The limestones are mainly massive, forming

Fig. 11. Laminated dolomites forming the core of the first carbonate buildup in the section at locality 11 (fig. 2).

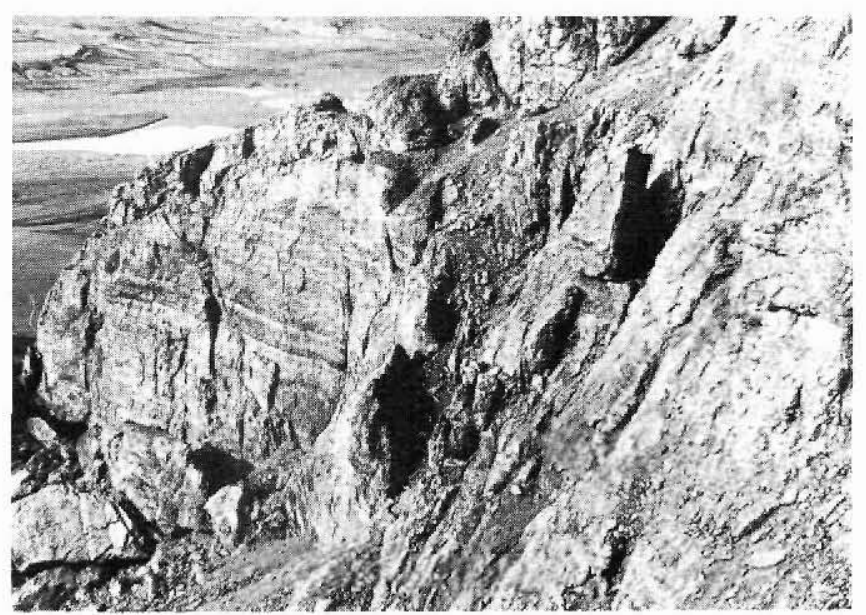




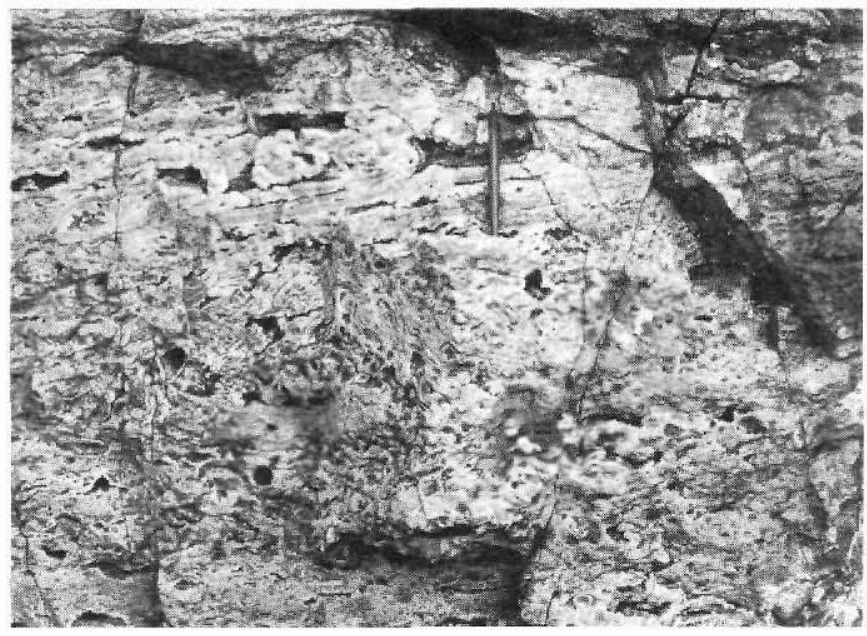

Fig. 12. Fenestral laminated dolomites from the first carbonate buildup in the section at locality 11 (fig. 2).

impressive bluffs, and are generally light to medium grey in colour. The first level of carbonate buildups occurs within this unit and it is composed of bright yellow vuggy dolomite (figs 11 , 12).

The base of the formation is marked by a 20 m thick very thin bedded $(c .10 \mathrm{~cm})$ dark grey, mottled, lime mudstone (fig. 10). Out of this level grows a $100 \mathrm{~m}$ thick carbonate buildup (fig. 11) mainly composed of fenestral dolomites (fig. 12). The relief of the mound varies from near horizontal, on the flanks, to vertical, and the mound interfingers with the surrounding flat bedded light grey lime mudstones and wackestones. The carbonate buildup is flanked by thick massive bio-breccia beds composed of coral and stromatoporoid debris which is not thoroughly dolomitised. Carbonate buildups at this stratigraphic level are not common, possibly only one other being observed in the immediate vicinity. Their environmental position is intriguing in that they are set back some 5 to $10 \mathrm{~km}$ from the carbonate shelf edge.

Away from the buildup, the normal flat bedded sediments which completely overlap the feature consist of massive bedded light grey lime wackestones and subordinate floatstones.

The whole unit is not very fossiliferous. Stromatoporoids and tabulate corals are commonly associated with the flank beds of the carbonate buildups and are rarer in the flat bedded carbonates. The basal beds contain a new virgianiid brachiopod possibly indicating an Early to Middle Llandovery (Rhuddanian - Idwian) age. This further suggests that the top of the Aleqatsiaq Fjord Formation is Silurian.

\section{Silurian carbonate formation 2}

The second un-named formation is a variable sequence of limestones up to $180 \mathrm{~m}$ thick which includes the second carbonate buildup level (figs $9 \& 10$ ). Generally, the unit is massive bedded in the immediate vicinity of the buildups but the surrounding level bedded carbonates are thin bedded and recessive. The nature of exposure of the buildups, with vertical cliff-faces, precludes examination; the only accessible parts are the flank beds.

The base of the formation is well marked by a $5 \mathrm{~m}$ thick unit of dark grey to black, very thin 
bedded ( $1-2 \mathrm{~cm})$, nodular, mottled lime mudstone. One examined carbonate buildup originates at this level and, in the core region, reaches at least $100 \mathrm{~m}$ thick. The flank beds consist entirely of graded crinoidal rudstones and stromatoporoid, tabulate coral rudstones. Proximal deposits of the buildup appear to contain talus breccia beds.

Three kilometers along strike, away from the carbonate buildup the sediments consist entirely of a monotonous sequence of thinly bedded $(5-10 \mathrm{~cm})$, dark weathering, black lime mudstones, mottled yellowish brown. The whole sequence is nodular and some horizons consist entirely of small spherical nodules $(c .1 \mathrm{~cm})$ imparting a honeycombed look to the rock. This facies interfingers with the carbonate buildup and its flank beds but it does not overwhelm the buildup.

In the area studied only two carbonate buildups were seen. Both were situated 5 to $6 \mathrm{~km}$ to the south of the edge of the carbonate shelf and the base of the overlying formation rests directly on them. Due to differential compaction, and initial relief associated with the buildup of carbonate, the contact with the overlying formation is undulating.

The fauna in the flat lying carbonates is poor and consists of a few disarticulated pentamerids (Harpidium sp.?) tabulate corals and stromatoporoids. Nearer the buildup the fauna is more abundant but it is essentially the same. The presence of Harpidium sp.? suggests a Late Llandovery (Fronian - Telychian) or younger age.

\section{Silurian carbonate formation 3}

This monotonous formation is $200 \mathrm{~m}$ thick and forms the prominent cliffs at the top of the Silurian carbonate sequence (fig. 9, 10). It is generally massive bedded $(c .5$ to $10 \mathrm{~m}$ ) with little internal stratification. The whole unit weathers light grey with a yellowish tinge but on outcrop, the rock is seen to be mottled light medium grey. Small calcite vugs and patches are scattered throughout the sediment which is mainly a lime mudstone or packstone. Some pockets of crinoidal rudstone occasionally occur as do very thin intraformational conglomerates.

The base of the formation was only accessible at the transition from the level bedded carbonates below. Here, an abrupt facies change from dark grey to black lime mudstones to light grey lime mudstones was observed. The base of Silurian carbonate formation 3 is marked by a thick intraformational conglomerate.

A rich fauna of trilobites, corals, stromatoporoids, brachiopods and crinoid debris occurs. The whole faunal aspect is suggestive of Late Llandovery (Fronian - Telychian) or younger, an assignment which is consistent with the presence of Harpidium sp.

\section{Silurian shale and breccia formation}

This formation is $240 \mathrm{~m}$ thick and comprises two members, here informally designated A and B (fig. 9).

\section{Member A (c. $140 \mathrm{~m})$.}

Member A consists of an alternation of laminated black graptolitic muds and limestone breccia beds up to $20 \mathrm{~m}$ thick. The shales are bituminous and account for 10 per cent of the succession. Many of the breccia beds are graded and laminated (fig. 13). The thicker ones contain boulders up to $5 \mathrm{~m}$ across and have erosive bases. Their structure is chaotic, without any sedimentary structures. 


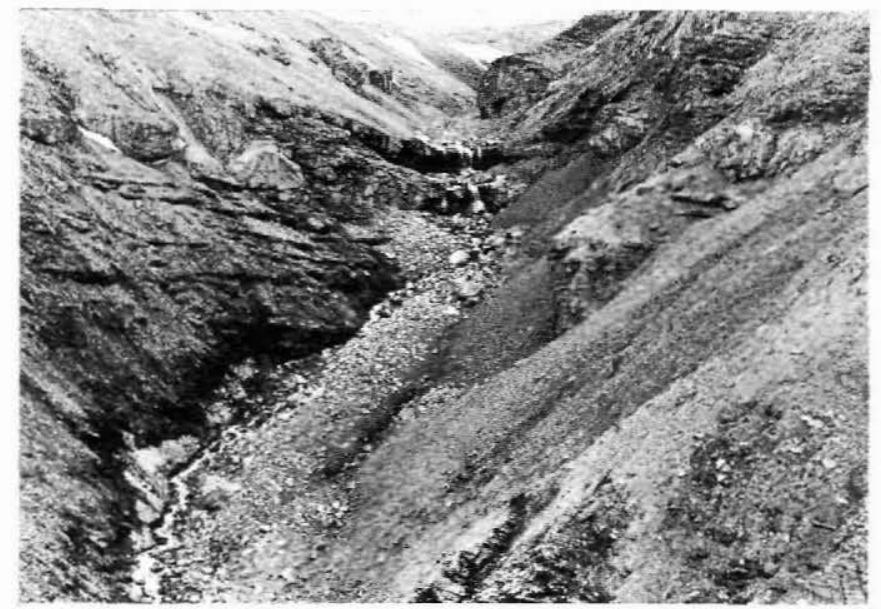

Fig. 13. Chaotic breccias derived from the carbonate buildup illustrated in fig. 14, interbedded with shale. Note the erosive character of the breccia beds. Base of section at locality 10 (fig. 2); the cliff in the foreground is $30 \mathrm{~m}$ high.

\section{Member $B(c .100 \mathrm{~m})$.}

An alternation of black laminated bituminous silty graptolitic shales with some limy shale interbeds up to $5 \mathrm{~cm}$ thick, accounts for 90 per cent of this member. The remaining 10 per cent of the succession consists of thin (up to $50 \mathrm{~cm}$ ) graded and laminated limestone breccia beds. The base of this member is marked by a persistent $20 \mathrm{~m}$ thick boulder breccia and the top by a 2 $\mathrm{m}$ thick cobble conglomerate.

\section{Silurian siltstone formation}

This formation which is $300 \mathrm{~m}$ thick conformably overlies Member B of the Silurian shale and breccia formation. Three members are recognised and informally designated A, B and C (figs 9 \& 14).

\section{Member $A$ (c. $60 \mathrm{~m})$.}

Member $\mathrm{A}$ is a fine to medium grained micaceous siltstone, which is medium grey to dark grey in colour. The silts are finely laminated and interbedded with thin $(c .5 \mathrm{~cm})$ lime mudstone horizons. Sporadic thin calcareous sandstone breccia $(c .1-5 \mathrm{~cm})$ with calcareous debris account for 2 per cent of the facies. On weathered surfaces the silts have a slight green tinge. The only fossils noted were very rare graptolites.

\section{Member $B(c .110 \mathrm{~m})$}

This consists mainly of fine to medium grained, laminated, micaceous siltstone. The whole unit is a distinctive green colour with, rarely, thin stringers of grey silt. Yellowish green claystone units are occasionally present, while thin calcareous sandstones up to $5 \mathrm{~cm}$ thick account for 5 per cent of the facies. Similarly, thin shelly coquinas with 'Clorinda' dormitzeri and fragmented orthocone cephalopods occur. Graptolites are rare but still the most consistently present fauna. 


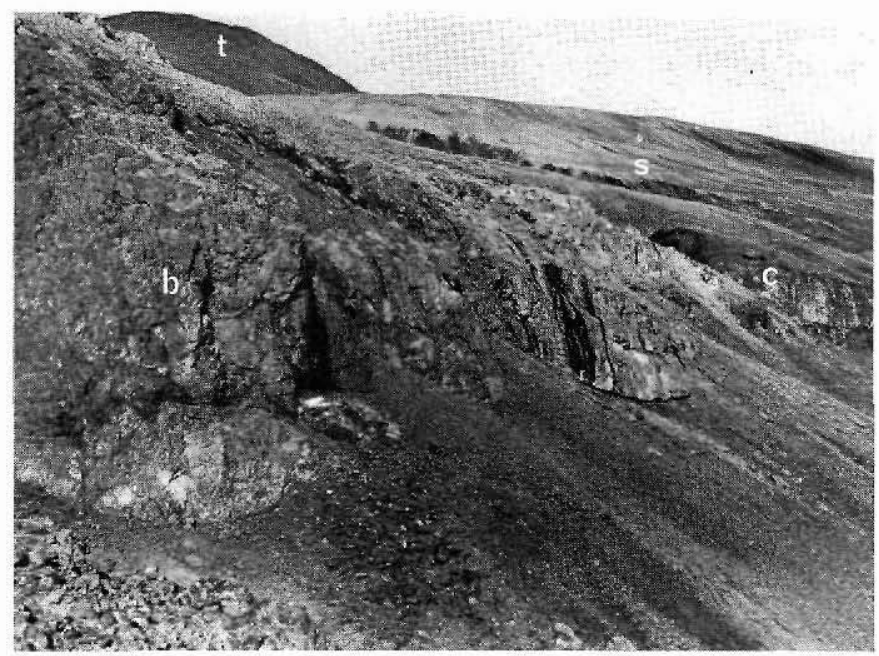

Fig. 14. Contact between Silurian shelf and shelf slope sequences at locality 13 (fig. 2). b, lime mud carbonate buildup with long axis perpendicular to the shelf slope contact; $c$, downslope carbonate breccias dipping from the buildup into shales, siltstones $(\mathrm{s})$ and turbidites $(\mathrm{t})$.

\section{Member C (c. $130 \mathrm{~m})$}

Member C comprises a sequence of dark grey, micaceous siltstones. Mica flakes over $3 \mathrm{~mm}$ wide are common and, rarely, thin micaceous sandstones occur. There are no coquinas and no fauna was located.

\section{Silurian turbidite formation}

In the section presented in fig. 9 only the basal $70 \mathrm{~m}$ of this formation was examined, although reconnaissance indicates that the formation is at least $500 \mathrm{~m}$ thick. The basal beds consist of very coarsely laminated sandy silt, interbedded with fine grained. massive or laminated, sole marked, sandstones up to $10 \mathrm{~cm}$ thick. The sandstones are almost white and appear quartzitic. The turbidites weather brown and are generally not as recessive as the underlying units. thus forming slightly stepped hills (fig. 15). The upper part of the unit consists of thicker, slightly coarser and darker sandstones, with thinner silt interbeds. The fauna is very infrequent although a few graptolites were found in the basal part of the sequence.

\section{Age of the Silurian clastic sequences}

Preliminary identification of graptolite faunas from the Silurian clastic sequences has been undertaken by M. Bjerreskov (written communication, 1978). The lowest faunas in member A of the Silurian shale and breccia formation include Monograptus spiralis spiralis, Retiolites geinitzianus angustidens, $M$. priodon, $M$. tullbergi, $M$. vomerinus and $M$. linnarssoni? indicating a latest Llandovery (Telychian) age. Immediately underlying the $20 \mathrm{~m}$ thick breccia at the top of 
the member, Monograptus riccartonensis?, $M$. priodon, $M$. vomerinus (very slender form) and $M$. sp. may indicate the Early Wenlock Riccartonensis Zone. The whole of the graptolitic fauna from member B of the Silurian shale and breccia formation and member A of the overlying Silurian siltstone formation indicates an Early Wenlock age. The basal $40 \mathrm{~m}$ of member B of the Silurian siltstone formation contains a graptolite fauna still indicative of Early Wenlock. The top $20 \mathrm{~m}$ contains Monograptus colonus?, M. dubius?, M. nilsonni and $M$. sp. indicating an Early Ludlow age. Thus, some $50 \mathrm{~m}$ intervenes between the last Early Wenlock forms and the first Early Ludlow forms. This presumably represents the total thickness of the Middle and Upper Wenlock, as there is no obvious evidence for non-sequences.

The age of member $\mathrm{C}$ of the Silurian siltstone formation and the base of the overlying Silurian(?) turbidite formation is unknown, although they both postdate Early Ludlow. The last dateable graptolite collection comes from member B, $130 \mathrm{~m}$ below the base of the turbidites.

\section{Basin - shelf contact}

In other areas of North Greenland the basin-shelf contacts are often characterised by the presence of carbonate buildups (Dawes, 1971, 1976a; Christie \& Peel, 1977; Mayr, 1976). Dawes $(1971,1976 \mathrm{a})$ inferred such buildups to be present in Wulff Land on the basis of regional photographic interpretation and the present study substantiates his inferrence (fig. 14). In Wulff Land the contact between basin and shelf is abrupt. The flat bedded carbonates of the shelf sequence abruptly pass northward into slightly inclined basinal clastics (figs. $14 \& 15$ ). The carbonates form topographically high features against which the basinal clastics abut. In the easternmost contact seen (fig. 2, locality 12; fig. 15) the bedded carbonates are only partially in contact with the basin clastics. The actual carbonate contact with the clastic sequence is marked by mound-like structures which are interpreted as downfaulted carbonate blocks.

A similar setting was examined at a nearby point (fig. 2, locality 13; fig. 14). Here, an an isolated knoll of flat to steeply bedded and slumped blue grey lime mudstone, with pockets of crinoidal and stromatoporoidal rudstone, passes northward into shales and siltstones (fig. 14). Breccia beds in the basinal clastics are derived from the carbonate areas and indicate a primary slope to the north (fig. 13).

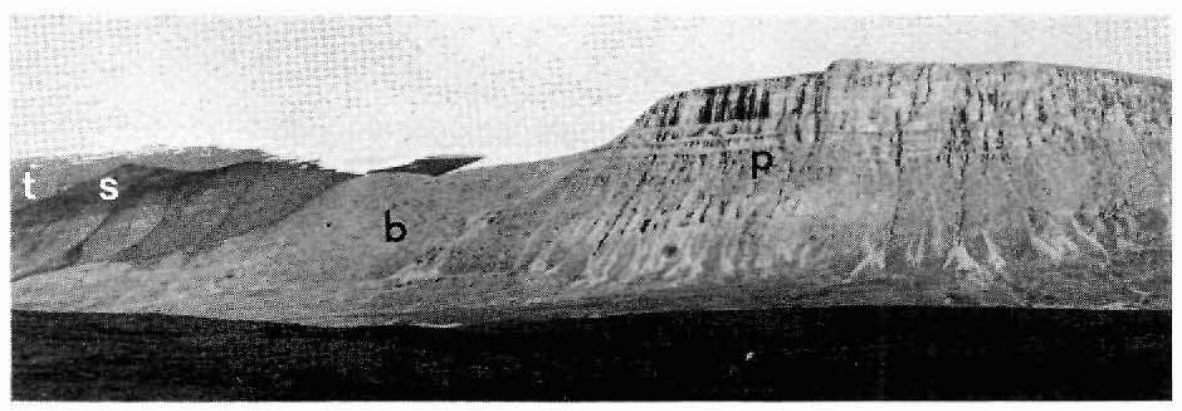

Fig. 15. Platform-basin contact at locality 12 (fig. 2). Downfaulted carbonate blocks (b) against Ordovician and Silurian carbonates (p). Basinal shales, siltstones (s) and turbidites (t) partially overlie the downfaulted blocks. 
The knoll is separated from the flat bedded shelf carbonates to the south by a valley, but it is noticeably below the highest carbonate formation. The nature of the contact between the flat bedded carbonates and the carbonate buildup is unknown. These carbonate buildups appear very similar to the foreslope mud mounds of Wilson (1974).

The uppermost thick chaotic breccia marking the top of member A of the Silurian shale and breccia formation correlates with the uppermost beds of the carbonate buildup at locality 13 (fig. 2). Thus, from preliminary identification of graptolite faunas in the shale, it appears as if the top of the carbonate buildup is no younger than Early Wenlock (Centrifugus - Riccartonensis Zones). Thin calcareous breccia and shelly coquina beds still occur above this level in the shale and breccia formation. They possibly indicate that the carbonate buildup was still a positive feature, providing a source of carbonate for erosion and also areas for benthic animal colonisation. However, carbonate sedimentation had probably ceased.

Topographic relationships suggest that the age of the flat bedded Silurian carbonate formation 3 may be younger than the carbonate buildup (fig. 15). Further, carbonate formation 3 is closely comparable to a group of sediments which cap carbonate buildups of late Llandovery to early Wenlock age in western Hall Land and northern Washington Land. From structural and stratigraphic relations in Wulff Land, and regional geological considerations, it is thought unlikely that carbonate formation 3 predates the late Llandovery and may possibly be Wenlock or Ludlow.

\section{References}

Christie, R.L. \& Peel, J.S. 1977: Cambrian-Silurian stratigraphy of Børglum Elv, Peary Land, eastern North Greenland. Rapp. Gronlands geol. Unders. 82, 48 pp.

Dawes, P.R. 1971: The North Greenland fold belt and environs. Bull. geol. Soc. Denmark 20, 197-239.

Dawes, P.R. 1976a: Precambrian to Tertiary of northern Greenland. In Escher, A. \& Watt, W.S. (edit.) Geology of Greenland, 248-303. Copenhagen: Geol. Surv. Greenland.

Dawes, P.R. 1976b: Reconnaissance of Eocambrian and Lower Palaeozoic strata in south-western Peary Land, North Greenland. Rapp. Grønlands geol. Unders. 80, 9-14.

Dawes, P.R. \& Soper, N.J. 1973: Pre-Quaternary history of North Greenland. In Pitcher, M.G. (edit.) Arctic Geology. Mem. Amer. Ass. Petrol. Geol. 19, 117-134.

Fritz, W.H. 1973: Medial Lower Cambrian trilobites from the Mackenzie Mountains Nortwestern Canada. Pap. geol. Surv. Canada 73-24, 43 pp.

Haller, J. 1961: The Carolinides: an orogenic belt of late Precambrian age in Northeast Greenland. In Raasch, G.O. (edit.) Geology of the Arctic 1, 155-159. Toronto U.P.

Henriksen, N. \& Peel, J.S. 1976: Cambrian - Early Ordovician stratigraphy in south-western Washington Land, western North Greenland. Rapp. Grønlands geol. Unders. 80, 17-23.

Jepsen, H.F. 1971: The Precambrian, Eocambrian and early Palaeozoic stratigraphy of the Jørgen Brønlund Fjord area, Peary Land, North Greenland. Bull. Grønlands geol. Unders. 96 (also Meddr Grønland 192,2) $42 \mathrm{pp}$.

Jepsen, H.F. \& Dueholm, K.S. 1978: Computer supported geological photointerpretation. Rapp. Grønlands geol. Unders. 90, 146-150.

Koch, L. 1920: Stratigraphy of Northwest Greenland. Meddr dansk geol. Foren. 5 (17), 78 pp.

Koch, L. 1929: Stratigraphy of Greenland. Meddr Grønland 73 (2), 2, 205-320.

Larsen, O. \& Dawes, P.R. 1974: K/Ar and Rb/Sr age determinations on Precambrian crystalline rocks in the Inglefield Land - Inglefield Bredning region. Thule district, western North Greenland. Rapp. Gronlands geol. Unders. 66, 4-8. 
Mayr, U. 1976: Middle Silurian reefs in southern Peary Land, North Greenland. Bull. Can. Petrol. Geol. 24, 440-449.

Peel, J.S. 1978: Geological investigations in Lower Palaeozoic terrain of northern Greenland between $78^{\circ} 30^{\prime} \mathrm{N}$ and $81^{\circ} 30^{\prime}$ N. Rapp. Grønlands geol. Unders. 90, 14-16.

Peel, J.S. 1979: Cambrian - Middle Ordovician stratigraphy of the Adams Gletscher region, south-west Peary Land, eastern North Greenland. Rapp. Gronlands geol. Unders. 88, 29-39.

Peel, J.S. \& Hurst, J.M. in press: Late Ordovician and earliest Silurian stratigraphy of Washington Land, western North Greenland. Rapp. Grønlands geol. Unders.

Troedsson, G.T. 1926: On the Middle and Upper Ordovician faunas of northern Greenland. I. Cephalopods. Meddr Gronland 71, 1-157.

Troedsson, G.T. 1928: On the Middle and Upper Ordovician faunas of northern Greenland. II. Meddr Grønland 72 (1), 1, $197 \mathrm{pp}$.

Troelsen J.C. 1950: Contributions to the geology of North west Greenland, Ellesmere Island and Axel Heiberg Island. Meddr Grønland 149 (7), 86 pp.

Wilson, J.L. 1974: Characteristics of carbonate platform margins. Bull. Am. Ass. Pet. Geol. 58, 810-824. 